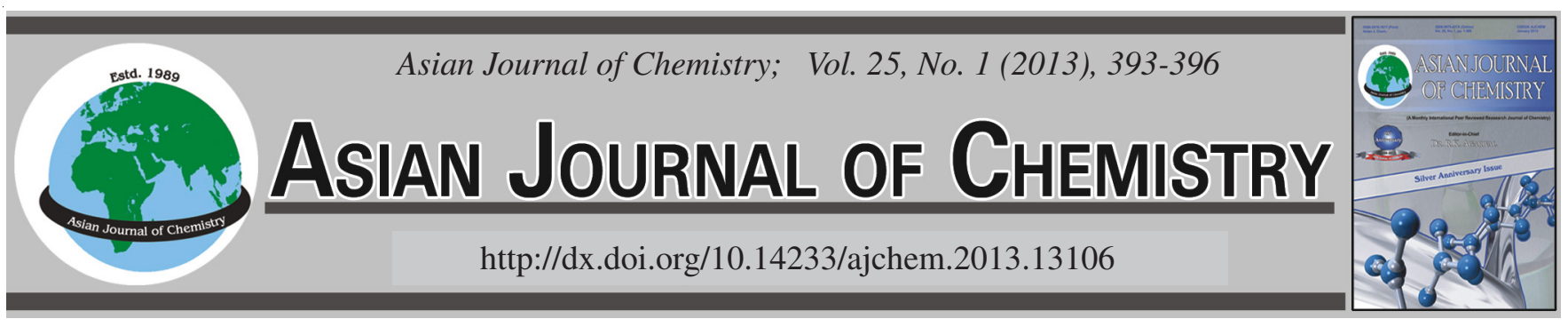

\title{
Green Synthetic Approach to 5-Substituted-1H-Tetrazoles via Recycle and Reuse of Tributyltin Chloride
}

\section{A. Sampath ${ }^{1, *}$, V. Prabhakar Reddy ${ }^{2}$, A. Kalyan Chakravarthy ${ }^{1}$ and P. Pratap Reddy ${ }^{3}$}

${ }^{1}$ Research and Development, Integrated Product Development, Innovation Plaza, Dr Reddy's Laboratories Ltd., Survey Nos. 42, 45, 46 and 54, Bachupally, Qutubullapur, Ranga Reddy District-500 123, India

${ }^{2}$ Department of Chemistry, P.G. College of Science, Osmania University, Saifabad, Hyderabad-500 004, India

${ }^{3}$ Research and Development, Macleods Pharmaceuticals Limited, G-2, Mahakali Caves Road, Andheri (E), Mumbai-400 093, India

*Corresponding author: E-mail: sampathreddyaalla@yahoo.com

A simple, safe and efficient process for the recycle of tributyltin chloride from tributyltin hydroxide is developed and its reuse in the synthesis of 5-substituted-1H-tetrazoles is successfully demonstrated, which paved a way to reduce the toxic tin waste significantly. Recycling of tributyltin chloride is possible over six cycles without loss of its activity.

Key Words: 5-Substituted-1H-tetrazole, [3+2] Cycloaddition, Nitrile, Recycle, Tributyltin chloride, Tributyltin hydroxide.

\section{INTRODUCTION}

The nitrogen-rich tetrazole moiety is an integral part of several molecules, which find application as propellants ${ }^{1}$, explosives $^{2}$ and pharmaceuticals ${ }^{3}$. Although many syntheses have been reported for tetrazoles ${ }^{4,5}$, the $[3+2]$ cycloaddition between nitrile component and alkyltin azide is the most known, preferable and efficiently practicable route ${ }^{4}$. Among the various alkyltin azides, the preferred is tributyltin azide keeping in view the availability, safety and solubility in the organic solvents ${ }^{6}$. Generation of tributyltin azide in situ from tributyltin chloride and sodium azide is a superior method, as it limits the risks that arise from handling the corresponding azide $^{7}$. Synthesis of tetrazole containing active pharmaceutical ingredients like valsartan, candesartan and irbesartan involves utilization of tributyltin chloride in the tetrazole ring construction $^{8}$. Usage of tributyltin chloride generates lot of toxic tin waste and leads to the environmentally unfriendly processes. However, the usage of tributyltin chloride becomes obligatory despite its toxicity and environmentally hazardous nature ${ }^{9}$, due to the superiority of [3+2] cycloaddition of nitrile and tributyltin azide amongst all other processes in terms of higher yields and scalability in producing tetrazoles.

It is widely recognized that there is a growing need for more environmentally friendly processes in the chemical industry. Even from an economic perspective it is very important that chemical processes are designed to minimize or recycle the waste produced. Curran et al. ${ }^{10}$ have recycled the fluorous tin bromide, used in the preparation of tetrazoles as fluorous tin chloride by acidic hydrolysis of stannyl tetrazole. But the usage of fluorous tin bromide is commercially not viable, as it is more expensive than tributyltin chloride. Moreover, treatment with acid poses safety issues as it generates hydrazoic acid if any unreacted azide is present in the reaction mixture. Hydrazoic acid is toxic and extremely explosive in organic solutions ${ }^{4}$. Recently Wang and co-workers ${ }^{11}$ recycled the tributyltin chloride via tributyltin fluoride by treating with sodium fluoride, which requires polytetrafluoroeth-ylene (PTFE) reactor and extreme care to deal with the highly corrosive and contact poisonous by-product, hydrofluoric acid. In addition, this process involves the fractional distillation of tributyltin chloride, increases the handling risk ${ }^{12}$. All together this process is less attractive in view of scalability and safety. Hence there arises a need to develop the safe and scalable process for recycle and reuse the tributyltin chloride in the synthesis of tetrazoles to minimize the toxic tin waste to the possible extent. Herein we describe a simple, safe and green synthetic approach to 5-substituted- $1 H$-tetrazoles via recycle and reuse of tributyltin chloride.

\section{EXPERIMENTAL}

Melting points are measured in open capillary tubes and are uncorrected. The ${ }^{1} \mathrm{H}$ NMR spectra were recorded on a Mercury plus Varian $400 \mathrm{MHz}$ NMR instrument using TMS as internal standard $(\delta=0.00 \mathrm{ppm})$. Chemical shifts are given in parts per million ( $\delta$-scale) and coupling constants are given 
in Hertz. IR spectra were recorded on a Perkin-Elmer FT IR instrument ( $\mathrm{KBr}$ pellet method). Mass spectra were recorded using a 4000-Q-trap LC-MS mass spectrometer.

General procedure for the synthesis of 5-substituted $\mathbf{1 H}$-tetrazoles (4a-j): Tributyltin chloride (2.5 equiv) and sodium azide ( 2.5 equiv) were charged to a solution of appropriate nitrile (1.0 equiv) in $o$-xylene $(20 \mathrm{~mL})$. The reaction mixture was stirred at reflux for stipulated time (Table-1). Then the reaction mixture was cooled to room temperature and a solution of sodium hydroxide $(2.5$ equiv) in water $(15 \mathrm{~mL})$ was added. After stirring for $1 \mathrm{~h}$ at room temperature, aqueous layer and organic layers were separated. The aqueous layer was diluted with water $(10 \mathrm{~mL})$, cooled to $5-10^{\circ} \mathrm{C}$ and acidified to $\mathrm{pH}$ - 2 with $6 \mathrm{~N}$ hydrochloric acid to precipitate the corresponding tetrazole, which was filtered after $1 \mathrm{~h}$ and dried. In case of tetrazoles $\mathbf{4} \mathbf{c}$ and $\mathbf{4 d}$, after acidified to $\mathrm{pH}-2$, product was extracted into ethyl acetate $(2 \times 10 \mathrm{~mL})$ and distilled completely. Dichloromethane $(10 \mathrm{~mL})$ was charged and distilled again to isolate the solid.

5-Benzyl-1H-tetrazole (4a): Yield: 78 \%; m.p. 121-123 ${ }^{\circ} \mathrm{C}$ (lit. $\left.{ }^{13} 123.1-123.8^{\circ} \mathrm{C}\right)$; IR (KBr, $\left.v_{\max } \mathrm{cm}^{-1}\right): 3444,1549,1533$, 1494, 1457, 1074, 1056, 892, 734, 711, 695, 673; ${ }^{1} \mathrm{H}$ NMR (400 MHz, DMSO- $\left.d_{6}\right): \delta=4.28\left(\mathrm{~s}, 2 \mathrm{H}, \mathrm{CH}_{2}\right), 7.20-7.40(\mathrm{~m}$, $5 \mathrm{H}$, aromatic); MS $(\mathrm{m} / \mathrm{z}): 161(\mathrm{M}+\mathrm{H})^{+}, 183(\mathrm{M}+\mathrm{Na})^{+}$.

5-(4'-Methyl-biphenyl-2-yl)-1H-tetrazole (4b): Yield: $82 \%$; m.p. $143-145{ }^{\circ} \mathrm{C}$ (lit. $\left.{ }^{14} 144{ }^{\circ} \mathrm{C}\right)$; IR (KBr, $\left.v_{\max }, \mathrm{cm}^{-1}\right)$ : 3428, 3121, 1601, 1567, 1483, 1396, 824, 756, 740; ${ }^{1} \mathrm{H}$ NMR (400 MHz, $\left.\mathrm{CD}_{3} \mathrm{OD}\right): \delta=2.31\left(\mathrm{~s}, 3 \mathrm{H}, \mathrm{CH}_{3}\right), 6.98(\mathrm{~d}, J=8.4$ $\mathrm{Hz}, 2 \mathrm{H}$, aromatic), 7.11 (d, $J=8.0 \mathrm{~Hz}, 2 \mathrm{H}$, aromatic), 7.54 (d, $J=8.0 \mathrm{~Hz}, 2 \mathrm{H}$, aromatic), 7.63 (d, $J=7.6 \mathrm{~Hz}, 2 \mathrm{H}$, aromatic); $\operatorname{MS}(\mathrm{m} / z): 237(\mathbf{M}+\mathrm{H})^{+}$.

5-Cyclopropyl-1H-tetrazole (4c): Yield: $73 \%$; m.p. 147$149{ }^{\circ} \mathrm{C}$ (lit. $\left.{ }^{15} 149-150{ }^{\circ} \mathrm{C}\right)$; IR $\left(\mathrm{KBr}, \mathrm{v}_{\max }, \mathrm{cm}^{-1}\right)$ : 3428, 3027, 2905, 1590, 1444, 1128, 1042; ${ }^{1} \mathrm{H}$ NMR (400 MHz, CD $\left.{ }_{3} \mathrm{OD}\right)$ : $\delta=1.05\left(\mathrm{~m}, 2 \mathrm{H}, \mathrm{CH}_{2}\right), 1.22\left(\mathrm{~m}, 2 \mathrm{H}, \mathrm{CH}_{2}\right), 2.21(\mathrm{~m}, 1 \mathrm{H}, \mathrm{CH})$; MS (m/z): $109(\mathrm{M}-\mathrm{H})^{-}$.

5-Butyl-1H-tetrazole (4d): Yield: $89 \%$; m.p. $45-47^{\circ} \mathrm{C}$ (lit. $\left.{ }^{13} 46-47^{\circ} \mathrm{C}\right)$; IR (KBr, $\left.v_{\max }, \mathrm{cm}^{-1}\right): 2960,1583,1550,1467$, 1260, 1108; ${ }^{1} \mathrm{H}$ NMR (400 MHz, $\mathrm{CDCl}_{3}$ ): $\delta=0.94$ (t, $J=7.2$ $\mathrm{Hz}, 3 \mathrm{H}, \mathrm{CH}_{3}$ ), 1.43 (sextet, $J=7.2 \mathrm{~Hz}, 2 \mathrm{H}, \mathrm{CH}_{3} \mathrm{CH}_{2} \mathrm{CH}_{2}$ ), 1.88 (p, $\left.J=7.2 \mathrm{~Hz}, 2 \mathrm{H}, \mathrm{CH}_{2} \mathrm{CH}_{2} \mathrm{CH}_{2}\right), 3.14$ (t, $J=7.6 \mathrm{~Hz}, 2 \mathrm{H}$, $\left.\mathrm{CH}_{2} \mathrm{CH}_{2} \mathrm{C}\right) ; \mathrm{MS}(\mathrm{m} / \mathrm{z}): 127(\mathrm{M}+\mathrm{H})^{+}$.

5-o-Tolyl-1H-tetrazole (4e): Yield: $80 \%$; m.p. 151-154 ${ }^{\circ} \mathrm{C}$ (lit. $\left.{ }^{13}, 153.2-153.8^{\circ} \mathrm{C}\right)$; IR (KBr, $\left.v_{\max }, \mathrm{cm}^{-1}\right)$ : 3430, 3128, 1607, 1563, 1485, 1386, 782, 746; ${ }^{1} \mathrm{H}$ NMR (400 MHz, DMSO- $\left.d_{6}\right): \delta=2.49\left(\mathrm{~s}, 3 \mathrm{H}, \mathrm{CH}_{3}\right), 7.38-7.71$ (m, 4H, aromatic); MS $(m / z): 161(\mathrm{M}+\mathrm{H})^{+}$.

5-(2-Nitro-phenyl)-1H-tetrazole (4f): Yield: $81 \%$; m.p. 157-159 ${ }^{\circ} \mathrm{C}$ (lit. ${ }^{13} 157.2-157.6^{\circ} \mathrm{C}$ ); IR ( $\left.\mathrm{KBr}, \mathrm{v}_{\max }, \mathrm{cm}^{-1}\right)$ : 3400 , $3085,1624,1583,1519,1486,1359,786,740 ;{ }^{1} \mathrm{H}$ NMR $(400$ MHz, DMSO- $\left.d_{6}\right): \delta=7.85-7.96(\mathrm{~m}, 3 \mathrm{H}$, aromatic), $8.19(\mathrm{~d}, J$ $=7.6 \mathrm{~Hz}, 1 \mathrm{H}$, aromatic); MS (m/z): $190(\mathrm{M}-\mathrm{H})^{-}$.

5-(3-Nitro-phenyl)-1H-tetrazole (4g): Yield: $77 \%$; m.p. 145-147 ${ }^{\circ} \mathrm{C}$ (lit. $\left..^{13} 144.7-145.6^{\circ} \mathrm{C}\right)$; IR (KBr, $\left.v_{\max }, \mathrm{cm}^{-1}\right)$ : 3400 , $3078,1627,1569,1529,1461,1349,872,823 ;{ }^{1} \mathrm{H}$ NMR (400 MHz, DMSO- $d_{6}$ ): $\delta=7.92(\mathrm{t}, J=8.4 \mathrm{~Hz}, 1 \mathrm{H}$, aromatic), 8.45 (d, $J=8.4 \mathrm{~Hz}, 1 \mathrm{H}$, aromatic), $8.49(\mathrm{~d}, J=8.0 \mathrm{~Hz}, 1 \mathrm{H}$, aromatic), 8.85 (s, 1H, aromatic); MS (m/z): $190(\mathrm{M}-\mathrm{H})^{-}$.
5-(4-Nitro-phenyl)-1H-tetrazole (4h): Yield: $81 \%$; m.p. 218-221 ${ }^{\circ} \mathrm{C}$ (lit. ${ }^{5 \mathrm{~d}} 218-220^{\circ} \mathrm{C}$ ); IR (KBr, $\left.v_{\max }, \mathrm{cm}^{-1}\right)$ : 3447, 3113, 2914, 2854, 1606, 1532, 1489, 1341, 867, 854; ${ }^{1} \mathrm{H}$ NMR (400 MHz, DMSO- $\left.d_{6}\right): \delta=8.31(\mathrm{~d}, J=8.8 \mathrm{~Hz}, 2 \mathrm{H}$, aromatic), 8.46 (d, $J=8.8 \mathrm{~Hz}, 2 \mathrm{H}$, aromatic); MS (m/z): $190(\mathrm{M}-\mathrm{H})^{-}$.

5-(2,4-Difluoro-phenyl)-1H-tetrazole (4i): Yield: $72 \%$; m.p. $142-144^{\circ} \mathrm{C}$; IR (KBr, $\left.v_{\max }, \mathrm{cm}^{-1}\right)$ : 3452, 3096, 1625, 1489 , 1360, 855, 822; ${ }^{1} \mathrm{H}$ NMR (400 MHz, DMSO- $\left.d_{6}\right): \delta=7.37$ (t, $J=8.0 \mathrm{~Hz}, 1 \mathrm{H}$, aromatic), $7.59(\mathrm{t}, J=9.2 \mathrm{~Hz}, 1 \mathrm{H}$, aromatic), $8.13\left(\mathrm{t}, J=8.8 \mathrm{~Hz}, 1 \mathrm{H}\right.$, aromatic); MS $(\mathrm{m} / \mathrm{z}): 181(\mathrm{M}+\mathrm{H})^{+}$.

5-(2-Bromo-phenyl)-1H-tetrazole $(\mathbf{4 j})$ : Yield: $73 \%$; m.p. $179-182^{\circ} \mathrm{C}$ (lit. $\left.{ }^{14} 181-183^{\circ} \mathrm{C}\right)$; IR (KBr, $\left.v_{\max }, \mathrm{cm}^{-1}\right)$ : 3429 , 3033, 1604, 1574, 1475, 1395, 773, 749; ${ }^{1} \mathrm{H}$ NMR (400 MHz, $\left.\mathrm{CD}_{3} \mathrm{OD}\right): \delta=7.48-7.57$ (m, $2 \mathrm{H}$, aromatic), $7.68(\mathrm{~d}, J=7.6 \mathrm{~Hz}$, $1 \mathrm{H}$, aromatic), $7.82(\delta, J=8.4 \mathrm{~Hz}, 1 \mathrm{H}$, aromatic); MS (m/z): 126 $(\mathrm{M}+\mathrm{H})^{+}$.

Procedure for recycle of tributyltin chloride: To a suspension of tributyltin hydroxide (1.0 equiv) in $o$-xylene (obtained after alkaline hydrolysis reaction) was added conc hydrochloric acid ( $35 \%$ assay, 1.0 equiv) at room temperature. After stirring for $0.5 \mathrm{~h}$, the reaction mixture was allowed to settle and the $o$-xylene layer containing tributyltin chloride was separated and reused in the synthesis of tetrazoles. To confirm the structure, $o$-xylene was removed under reduced pressure and analyzed for IR and ${ }^{1} \mathrm{H}$ NMR spectral data. IR $\left(\mathrm{KBr}, v_{\max }, \mathrm{cm}^{-1}\right): 2957,2925,2872,2855,1463,1377,1075$, 876; ${ }^{1} \mathrm{H}$ NMR $\left(400 \mathrm{MHz}, \mathrm{CDCl}_{3}\right): \delta=0.87-0.97\left(\mathrm{~m}, 9 \mathrm{H}, \mathrm{CH}_{3}\right)$, 1.27-1.39 (m, $12 \mathrm{H}, \mathrm{CH}_{3} \mathrm{CH}_{2} \mathrm{CH}_{2}$ ), 1.61-1.68 (m, 6H, $\left.\mathrm{CH}_{2} \mathrm{Sn}\right)$.

\section{RESULTS AND DISCUSSION}

$[3+2]$ Cycloaddition of nitrile compound and tributyltin azide, generated in situ provides tributyltin protected tetrazole. Removal of the tributyltin moiety from the tetrazole ring can be achieved by treatment with sodium hydroxide, wherein tributyltin hydroxide would be obtained as a by-product (Scheme-I). Basic hydrolysis would generate sodium azide instead of hydrazoic acid, if unreacted tin azide is present in the reaction mixture. Sodium azide is not explosive, but decomposes in a more controlled way upon heating, releasing spectroscopically pure $\mathrm{N}_{2}$ gas ${ }^{16}$. It was envisioned that the thus obtained tributyltin hydroxide can be recycled as tributyltin chloride, which can be used in the tetrazole ring construction. To the best of our knowledge such approach is hitherto not reported earlier.

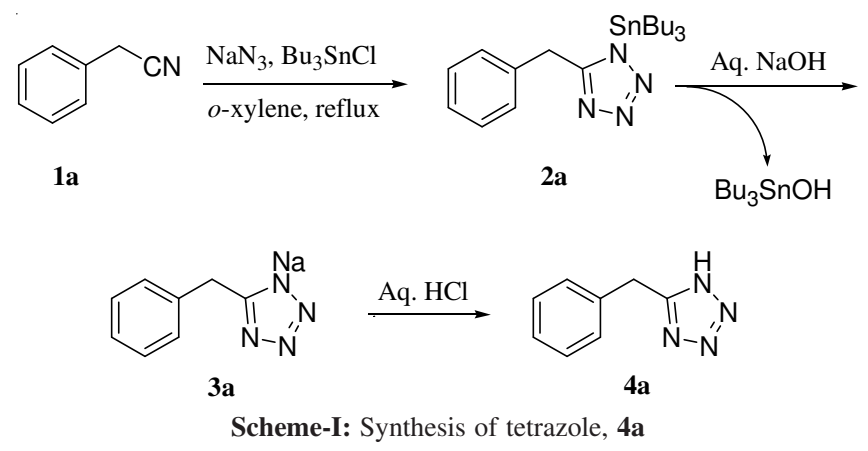

As a representative example, benzylcyanide (1a) was treated with the sodium azide and tributyltin chloride in 
$o$-xylene at reflux temperature to result in the tributyltin substituted tetrazole derivative $\mathbf{2 a}$. At this point, quenching of the reaction with aqueous sodium hydroxide resulted in tributyltin hydroxide which forms a suspension with the organic layer while the sodium salt of tetrazole $\mathbf{3 a}$ is retained in the aqueous layer. Acidification of the aqueous layer resulted in the free tetrazole, 5-benzyltetrazole (4a), which precipitated as a solid in $78 \%$ yield (Scheme-I).

Our next task was to convert the tributyltin hydroxide to tributyltin chloride. Tributyltin hydroxide suspended in $o$ xylene was treated with conc $\mathrm{HCl}$ at room temperature to furnish the tributyltin chloride (Scheme-II). The dissolution of the suspension indicated the formation of tributyltin chloride as it is highly soluble in $o$-xylene and further confirmed by spectral data.

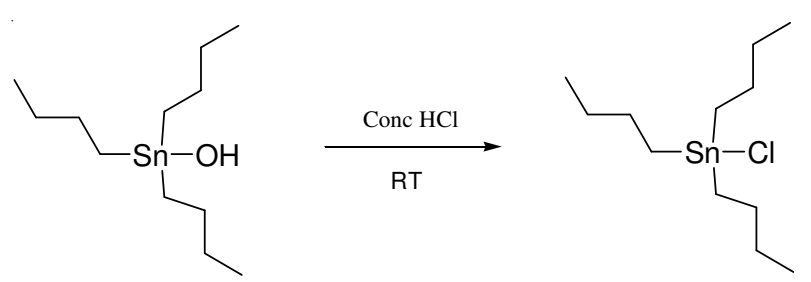

Scheme-II: Synthesis of tributyltin chloride

Having achieved the regeneration of tributyltin chloride, the crucial reuse of the recycled tributyltin chloride was studied. To the $o$-xylene layer containing the regenerated tributyltin chloride was added sodium azide and nitrile compound 1a and refluxed to result in the tetrazole in a yield of $78 \%$ following the work up procedure mentioned above. The tributyltin hydroxide generated was once again recycled to tributyltin chloride and reused. Such sequence of reactions was performed six times and in all the cases the yield of the product was consistent (Fig. 1). These consistent results are indicating that, the recovery of tributyltin chloride can be extended to more than six cycles.

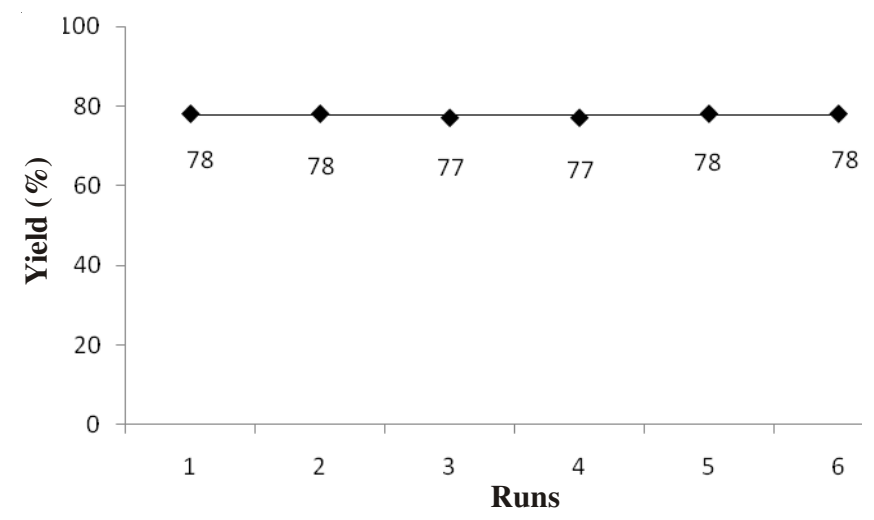

Fig. 1. Reusability testing of recycled tributyltin chloride

The cycle pathway of recycle and reuse of tributyltin chloride in the synthesis of 5-substituted- $1 H$-tetrazole can be represented as in Fig. 2. Tributyltin chloride reacts with sodium azide to furnish tributyltin azide, which undergoes [3+2] cycloaddition with nitrile compound to produce tributyltin protected tetrazole. Upon treatment with sodium hydroxide, tributyltin moiety will be released as tributyltin hydroxide.
On treatment with hydrochloric acid, tributyltin hydroxide gets converted into tributyltin chloride. By this manner, tributyltin chloride will be regenerated continuously without loss of its activity and it can be reused in the tetrazole ring construction.

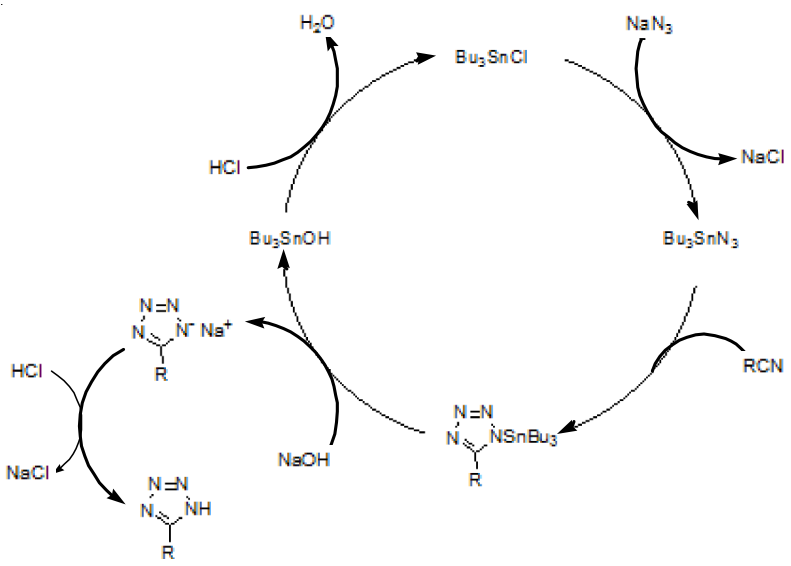

Fig. 2. Cyclic pathway of recycle and reuse of tributyltin chloride

Recovery and reuse of tributyltin chloride concept was extended to nine other aromatic and aliphatic nitrile compounds to check the versatility of greener approach and resulted in the tetrazoles in good yields (Table-1). It can be further extended for the synthesis of tetrazole containing active pharmaceutical ingredients, such as valsartan, candesartan and irbesartan.

For nitriles $\mathbf{1 b}$ and $\mathbf{1 j}$, the reported reaction times using 1 equivalent each of tributyltin chloride and sodium azide are $43 \mathrm{~h}$ and $48 \mathrm{~h}$, respectively ${ }^{17,18}$. During the studies, it was observed that the quantity of tributyltin chloride and sodium azide played a pivotal role in the rate of reaction. It was observed that, with 2.5 equivalents each of tributyltin chloride and sodium azide for nitriles $\mathbf{1 b}$ and $\mathbf{1 j}$, the reaction was completed within $6 \mathrm{~h}$ and $4 \mathrm{~h}$, respectively, in good yields. Hence a combination of 2.5 equivalents of tributyltin chloride and 2.5 equivalents of sodium azide was found to be effective, the reaction being completed in shorter period (Table-1). Further increase in the molar ratio had no significant impact on the rate of reaction.

\section{Conclusion}

In conclusion, it was demonstrated that tributyltin hydroxide, the by-product in tetrazole ring construction can be recycled to tributyltin chloride without loss in activity and reused over several cycles in the synthesis of 5-substituted $1 \mathrm{H}$-tetrazoles. A safe and easily scalable process having advantages over the reported processes was developed for the recycle of tributyltin chloride. Furthermore, this methodology paved a way to develop a greener synthetic approach to 5 -substituted $1 H$-tetrazoles, reducing the toxic tin waste produced in the tetrazole ring construction.

\section{ACKNOWLEDGEMENTS}

One of the authors (AS) thank the Management of DRL for providing facility to carry out this work. AS also gratefully acknowledged the Analytical and Research and Development Departments for their support. 


(n)

1. T.M. Klapotke, in eds.: R.E. and W. de Gruyter, Moderne Anorganische Chemie, Berlin, Germany, edn. 3, pp 99-104 (2007).
2. (a) T.M. Klapotke, High Energy Density Materials, Springer: Berlin, Germany, pp. 85-122 (2007); (b) T. Fendt, N. Fischer, T.M. Klapotke and J. Stierstorfer, Inorg. Chem., 50, 1447 (2011).

3. (a) R.H. Bradbury, C.P. Allott, M. Dennis, J.A. Girdwood, P.W. Kenny, J.S. Major, A.A. Oldham, A.H. Ratcliffe and J.E. Rivet, J. Med. Chem., 36, 1245 (1993); (b) M. Koyama, N. Ohtani, F. Kai, I. Moriguchi and S. Inouye, J. Med. Chem., 30, 552 (1987), (c) K. Raman, S.S. Parmer and S.P. Singh, J. Heterocycl. Chem., 17, 1137 (1980); (d) J.R. Maxwell, D.A. Wasdahl, A.C. Wolfson and V.I. Stenberg, J. Med. Chem., 27, 1565 (1984).

4. R.J. Herr, Bioorg. Med. Chem., 10, 3379 (2002) and references cited therein.

5. (a) D. Amantini, R. Beleggia, F. Fringuelli, F. Pizzo and L. Vaccoro, J. Org. Chem., 69, 2896 (2004); (b) T. Jin, F. Kitahara, S. Kamijo and Y. Yamamoto, Tetrahedron Lett., 49, 2824 (2008); (c) M. Nasrollahzadeh, D. Habibi, Z. Shahkarami and Y. Bayat, Tetrahedron, 65, 10715, 2009; (d) A.N. Chermahini, A. Teimouri, F. Momenbeik, A. Zarei, Z. Dalirnasab, A. Ghaedi and M. Roosta, J. Heterocycl. Chem., 47, 913 (2010); (e) Y. Zhou, C. Yao, R. Ni and G. Yang, Synth. Commun., 40, 2624 (2010).

6. (a) S.J. Wittenberger, Org. Prep. Proced. Int., 26, 499 (1994); (b) In Comprehensive Heterocyclic Chemistry II, R.N. Butler, A.R. Katritzky, C.W. Rees, E.F.V. Scriven, Pergamon: Oxford, Vol. 4, p. 621 (1996).

7. D.J. Carini, J.V. Duncia, P.E. Aldrich, A.T. Chui, A.L. Johnson, M.E. Pierce, W.A. Price, J.B. Santella III, G.J. Wells, R.R. Wexler, P.C. Wong, S.E. Yoo and P.B.M.W.M. Timmermans, J. Med. Chem., 34, 2525 (1991).

8. (a) I. Saxena, A. Nath and M. Prasad, US Patent 7943794 B2 (2011); (b) P. Buhlmayer, F. Ostermayer and T. Schmidlin, US Patent 5399578 (1995); (c) U. Beutler, M. Boehm, P.C. Fuenfschilling, T. Heinz, J.P. Mutz, U. Onken, M. Mueller and W. Zaugg, Org. Proc. Res. Dev., 11, 892 (2007); (d) R.R. Soni, S.L. Vasoya, R.C. Ghotikar, A.K. Pandey and H.R. Shah, US Patent 7923567 (2011); (e) Y. Kumar, K.V. Ramana, M. Prasad, A. Nath, S. Sathyanarayana and B. Vijayaraghavan, WO Patent 2005/051929 A1 (2005); (f) P.B. Deshpande, P. Luthra, A. Pandey, WO Patent 2007/054965 A2 ( 2007); (g) K.V.V.P. Rao, R. Dandala, V.K. Handa, I.V.S. Rao, A. Rani and A. Naidu, Syn. Commun., 37, 2897 (2007); (h) T. Naka, K. Nishikawa and T. Kato, US Patent 5196444 (1993).

9. (a) J.T. Jagatap, K.B. Shejule and D.P. Jaiswal, World J. Fish Marine Sci., 3, 100 (2011); (b) R. Adema-Hannes and J. Shenker, Environ. Toxicol. Chem., 27, 2131 (2008); (c) P. Dimitrion, J. Castritsi-Catharios and H. Miliou, Ecotoxicol. Environ. Saf., 54, 30 (2003); (d) R. Ogata, M. Omura, Y. Shimasaki, K. Kubo, Y. Oshima, S. Aou and N. Inoue, J. Toxicol. Environ. Health A., 63, 127 (2001).

10. D.P. Curran, S. Hadida and S.Y. Kim, Tetrahedron, 55, 8997 (1999).

11. G.X. Wang, B.P. Sun and C.H. Peng, Org. Process. Res. Dev., 15, 986 (2011).

12. T. Kato and Y. Shida, US Patent 5484955 (2009).

13. B.S. Jursic and B.W. LeBlanc, J. Heterocycl. Chem., 35, 405 (1998).

14. S.J. Wittenberger and B.G. Donner, J. Org. Chem., 58, 4139 (1993).

15. L.D. Hansen, E.J. Baca and P. Scheiner, J. Heterocycl. Chem., 7, 991 (1970).

16. E. Wiberg, N. Wiberg and A.F. Holleman, The Nitrogen Group. Inorganic Chemistry, Academic Press. p. 625 (2001).

17. J.V. Duncia, M.E. Pierce and J.B. Santella III, J. Org. Chem., 56, 2395 (1991).

18. D.B. Reitz, US Patent 5196537 (1993). 